\title{
Major- and Trace-Element Concentrations in Rock Samples Collected in 2005 from the Taylor Mountains 1:250,000-scale Quadrangle, Alaska
}

By Edward P. Klimasauskas ${ }^{1}$, Marti L. Miller ${ }^{1}$, Dwight C. Bradley ${ }^{1}$, Tom K. Bundtzen ${ }^{2}$, and Travis L. Hudson ${ }^{3}$

Open-File Report 2006-1306

\footnotetext{
${ }^{1}$ U.S. Geological Survey, Anchorage, Alaska

${ }^{2}$ Pacific Rim Geological Consulting, Fairbanks, Alaska

${ }^{3}$ Applied Geology, Inc., Sequim, Washington
} 


\section{U.S. Department of the Interior \\ Dirk Kempthorne, Secretary}

\section{U.S. Geological Survey Mark Myers Director}

U.S. Geological Survey, Reston, Virginia 2006

For product and ordering information:

World Wide Web: http://www.usgs.gov/pubprod

Telephone: 1-888-ASK-USGS

For more information on the USGS - the Federal source for science about the Earth, its natural and living resources, natural hazards, and the environment:

World Wide Web: http://www.usgs.gov

Telephone: 1-888-ASK-USGS

This report is preliminary and has not been reviewed for conformity with U.S. Geological Survey editorial standards or with the North American Stratigraphic Code. Any use of trade, firm, or product names is for descriptive purposes only and does not imply endorsement by the U.S. Government.

This Report has not been reviewed for geologic nomenclature

Although this report is in the public domain, permission must be secured from the individual copyright owners to reproduce any copyrighted material contained within this report. 


\section{Contents}

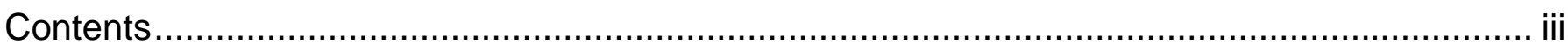

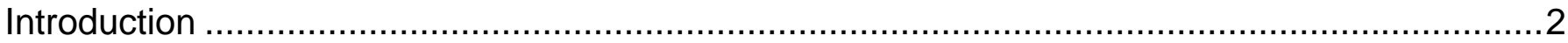

Sample Preparation and Analysis ……………

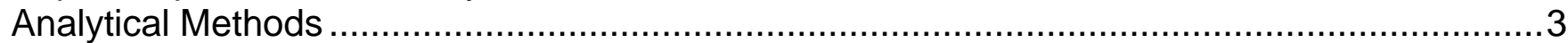

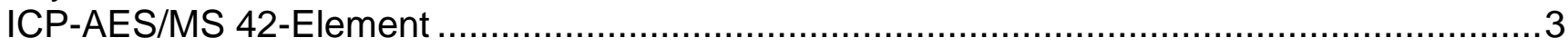

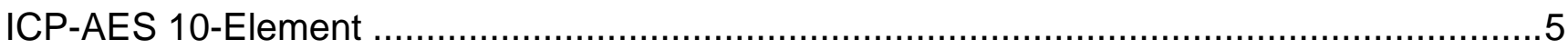

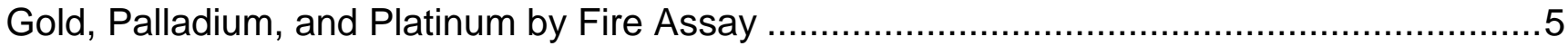

Mercury by Cold Vapor Atomic Absorption Spectrometry ............................................

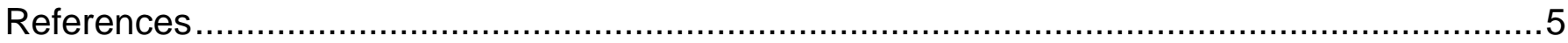

\section{Figures}

Figure 1. Index map showing location of Taylor Mountains 1:250,000-scale quadrangle, Alaska.

Figure 2. Locations of rock samples collected in the Taylor Mountains 1:250,000-scale quadrangle (Alaska) by the USGS in 2005

\section{Tables}

Table 1. Elements determined by 42-element ICP-AES/MS showing lower and upper reporting limits.

4

Table 2. Elements determined by 10-element ICP-AES showing lower and upper reporting limits. 


\section{Introduction}

The Kuskokwim mineral belt of Bundtzen and Miller (1997) forms an important metallogenic region in southwestern Alaska that has yielded more than 3.22 million ounces of gold and 400,000 ounces of silver. Precious-metal and related deposits in this region associated with Late Cretaceous to early Tertiary igneous complexes extend into the Taylor Mountains 1:250,000scale quadrangle. The U.S. Geological Survey is in the process of conducting a mineral resource assessment of this region. This report presents analytical data from 412 rock geochemistry samples collected by the U.S. Geological Survey during the 2005 field season. All samples were analyzed using the ICP-AES/MS42, ICP-AES10, fire assay, and cold vapor atomic absorption methods described in more detail below. Analytical values are provided in percent (\% or pct: 1 gram per 100 grams), parts per million (ppm: 1 gram per 1,000,000 grams), or parts per billion (ppb: 1 gram per 1,000,000,000 grams) as indicated in the column heading of the data table. Data are provided for download in Excel (*.xls), comma delimited (*.csv), dBase 4 (*.dbf) and as a point coverage in ArcInfo interchange (*.e00) formats available at http://pubs.usgs.gov/of/2006/1306/.

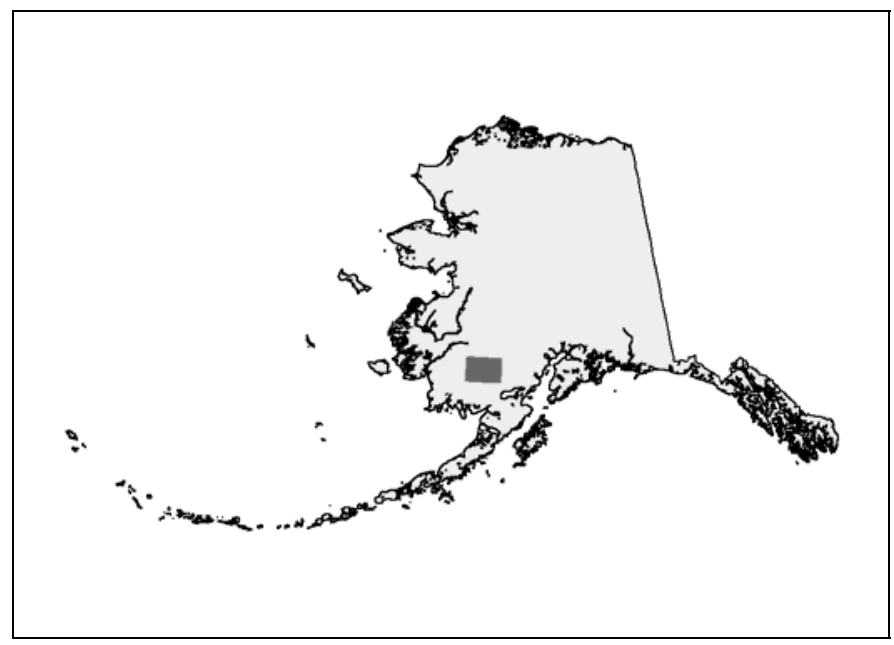

Figure 1. Location (dark shaded box) of Taylor Mountains 1:250,000-scale quadrangle, Alaska 




Figure 2. Location of samples (white circles) collected in the Taylor Mountains 1:250,000-scale quadrangle (Alaska) by the USGS in 2005.

\section{Sample Preparation and Analysis}

Samples were prepared for analysis at the U.S. Geological Survey laboratories in Denver, Colorado. Rock samples were crushed in a jaw crusher, then ground in a vertical pulverizer to less than 100 mesh (<150 microns), followed by thorough mixing to ensure homogeneity (Taylor and Theodorakos, 2002). Analyses were made by XRAL Laboratories in Don Mills, Ontario, Canada, under contract to the USGS. Rock reference materials and a series of multi-element solution standards were used for calibration and quality assurance and quality control (QA/QC) purposes (Taggart, 2002).

\section{Analytical Methods}

\section{ICP-AES/MS 42-Element}

A 0.25 gram portion of each sample was decomposed using a mixture of hydrochloric, nitric, perchloric, and hydrofluoric acids at low temperature. Digested samples were analyzed for 42 major, minor, and trace elements simultaneously by a combination of inductively coupled plasma atomic emission spectrometry (ICP-AES) and mass spectrometry (ICP-MS) (modified from Briggs and Meier, 2002). 
Table 1. Elements determined by 42-element ICP-AES/MS showing lower and upper reporting limits.

\begin{tabular}{|c|c|c|}
\hline Element & Lower reporting limit & Upper reporting limit \\
\hline Aluminum, $\mathrm{Al}$ & $0.01 \%$ & $15 \%$ \\
\hline Calcium, Ca & $0.01 \%$ & $15 \%$ \\
\hline Iron, Fe & $0.01 \%$ & $15 \%$ \\
\hline Potassium, K & $0.01 \%$ & $15 \%$ \\
\hline Magnesium, Mg & $0.01 \%$ & $15 \%$ \\
\hline Sodium, $\mathrm{Na}$ & $0.01 \%$ & $15 \%$ \\
\hline Phosphorous, P & $50 \mathrm{ppm}$ & $10,000 \mathrm{ppm}$ \\
\hline Titanium, Ti & $0.01 \%$ & $15 \%$ \\
\hline Silver, Ag & $1 \mathrm{ppm}$ & $10 \mathrm{ppm}$ \\
\hline Arsenic, As & $1 \mathrm{ppm}$ & $10,000 \mathrm{ppm}$ \\
\hline Barium, Ba & $5 \mathrm{ppm}$ & $10,000 \mathrm{ppm}$ \\
\hline Beryllium, Be & $0.1 \mathrm{ppm}$ & 100 ppm \\
\hline Bismuth, Bi & $0.04 \mathrm{ppm}$ & $10,000 \mathrm{ppm}$ \\
\hline Cadmium, Cd & $0.1 \mathrm{ppm}$ & $10,000 \mathrm{ppm}$ \\
\hline Cerium, Ce & $0.05 \mathrm{ppm}$ & $1,000 \mathrm{ppm}$ \\
\hline Cobalt, Co & $0.1 \mathrm{ppm}$ & $10,000 \mathrm{ppm}$ \\
\hline Chromium, Cr & $1 \mathrm{ppm}$ & $10,000 \mathrm{ppm}$ \\
\hline Cesium, Cs & $0.05 \mathrm{ppm}$ & $1,000 \mathrm{ppm}$ \\
\hline Copper, $\mathrm{Cu}$ & $0.5 \mathrm{ppm}$ & $10,000 \mathrm{ppm}$ \\
\hline Gallium, Ga & $0.05 \mathrm{ppm}$ & 500 ppm \\
\hline Indium, In & $0.02 \mathrm{ppm}$ & 500 ppm \\
\hline Lanthanum, La & $0.5 \mathrm{ppm}$ & $1000 \mathrm{ppm}$ \\
\hline Lithium, Li & $1 \mathrm{ppm}$ & $50,000 \mathrm{ppm}$ \\
\hline Manganese, Mn & $5 \mathrm{ppm}$ & $10,000 \mathrm{ppm}$ \\
\hline Molybdenum, Mo & $0.05 \mathrm{ppm}$ & $10,000 \mathrm{ppm}$ \\
\hline Niobium, Nb & $0.1 \mathrm{ppm}$ & $1,000 \mathrm{ppm}$ \\
\hline Nickel, Ni & $0.5 \mathrm{ppm}$ & $10,000 \mathrm{ppm}$ \\
\hline Lead, Pb & $0.5 \mathrm{ppm}$ & $10,000 \mathrm{ppm}$ \\
\hline Rubidium, Rb & $0.2 \mathrm{ppm}$ & $10,000 \mathrm{ppm}$ \\
\hline Sulfur, S & $0.01 \%$ & $5 \%$ \\
\hline Antimony, Sb & $0.05 \mathrm{ppm}$ & $10,000 \mathrm{ppm}$ \\
\hline Scandium, Sc & $0.1 \mathrm{ppm}$ & $1,000 \mathrm{ppm}$ \\
\hline Tin, Sn & $0.1 \mathrm{ppm}$ & $1,000 \mathrm{ppm}$ \\
\hline Strontium, Sr & $0.5 \mathrm{ppm}$ & $10,000 \mathrm{ppm}$ \\
\hline Tellurium, Te & $0.1 \mathrm{ppm}$ & 500 ppm \\
\hline Thallium, $\mathrm{Tl}$ & $0.1 \mathrm{ppm}$ & $10,000 \mathrm{ppm}$ \\
\hline Thorium, Th & $0.2 \mathrm{ppm}$ & $10,000 \mathrm{ppm}$ \\
\hline Uranium, U & $0.1 \mathrm{ppm}$ & $10,000 \mathrm{ppm}$ \\
\hline Vanadium, V & $1 \mathrm{ppm}$ & $10,000 \mathrm{ppm}$ \\
\hline Tungsten, W & $0.1 \mathrm{ppm}$ & $10,000 \mathrm{ppm}$ \\
\hline Yttrium, Y & $0.1 \mathrm{ppm}$ & $10,000 \mathrm{ppm}$ \\
\hline Zinc, Zn & $1 \mathrm{ppm}$ & $10,000 \mathrm{ppm}$ \\
\hline
\end{tabular}




\section{ICP-AES 10-Element}

Ten loosely bound metals (Ag, As, $\mathrm{Au}, \mathrm{Bi}, \mathrm{Cd}, \mathrm{Cu}, \mathrm{Mo}, \mathrm{Pb}, \mathrm{Sb}$, and $\mathrm{Zn}$ ) were solubilized by treatment of 1.0 gram of sample with a hydrochloric acid-hydrogen peroxide solution then extracted as organic halides using a 10\% aliquot 336-diisobutylketone (DIBK) solution. Organic halide solutions were then quantified using ICP-AES (modified from Matooka, 1996).

Table 2. Elements determined by 10-element ICP-AES showing lower and upper reporting limits.

\begin{tabular}{|lcc|}
\hline Element & $\begin{array}{c}\text { Lower reporting limit } \\
\text { (ppm) }\end{array}$ & $\begin{array}{c}\text { Upper reporting limit } \\
\text { (ppm) }\end{array}$ \\
\hline Silver, Ag & 0.08 & 400 \\
Arsenic, As & 1 & 6,000 \\
Gold, Au & 0.1 & 1,500 \\
Bismuth, Bi & 1 & 6,000 \\
Cadmium, Cd & 0.05 & 500 \\
Copper, Cu & 0.05 & 500 \\
Molybdenum, Mo & 0.1 & 900 \\
Lead, Pb & 1 & 6,000 \\
Antimony, Sb & 1 & 6,000 \\
Zinc, Zn & 0.05 & 500 \\
\hline
\end{tabular}

Gold, Palladium, and Platinum by Fire Assay

A 30 gram portion of each sample was mixed in a crucible with 150 grams of flux, followed by addition of $1 \mathrm{mg}$ of silver nitrate and covered with borax. Crucibles were placed in a furnace for 45 minutes at $1080^{\circ} \mathrm{C}$. The resulting dore bead was heated to remove all lead then digested in a mixture of nitric acid and hydrochloric acid. The final solution was adjusted to $10 \mathrm{ml}$ and analyzed by ICP-MS. The lower reporting limits were $1 \mathrm{ppb}$ for gold and palladium and $0.5 \mathrm{ppb}$ for platinum. The upper reporting limits for all three were 10,000 ppb (Detra, 2006).

\section{Mercury by Cold Vapor Atomic Absorption Spectrometry}

Analysis of mercury $(\mathrm{Hg})$ was obtained by digestion of $0.1 \mathrm{~g}$ of sample in a mixture of nitric and hydrochloric acids. Addition of potassium permanganate, sulphuric acid, and potassium persulphate, was followed by addition of a NaCl-hydroxylamine solution. Dilution completed the sample preparation. Mercury concentrations were determined using a Perkin-Elmer Flow Injection Mercury System, FIMS-100; the lower reporting limit of 0.02 ppm (modified from Brown and others, 1997).

\section{References}

Briggs, P.H. and Meier, A.L., 2002, The determination of forty-two elements in geological materials by inductively coupled plasma-mass spectrometry, in Taggart, J.E. Jr., ed., Analytical methods for chemical analysis of geologic and other materials, U.S. Geological Survey: U.S. Geological Survey Open-File Report 02-0223, Chapter I, at http://pubs.usgs.gov/of/2002/ofr-020223/, last accessed on January 3, 2006. 
Brown, Z.A., O’Leary, R.M., Hageman, P.L., and Crock, J.G., 1997, Mercury in water, geologic, and plant materials by continuous flow-cold vapor-atomic absorption spectrometry, in Taggart, J.E. Jr., ed., Analytical methods for chemical analysis of geologic and other materials, U.S. Geological Survey: U.S. Geological Survey Open-File Report 02-0223, Chapter M, at http://pubs.usgs.gov/of/2002/ofr-02-0223/, last accessed on January 3, 2006.

Bundtzen, T.K., and Miller, M.L., 1997, Precious metals associated with Late Cretaceous-early Tertiary igneous rocks of southwestern Alaska: Economic Geology, Monograph 9, p. 242-286.

Detra, D. E. (ddetra@usgs.gov), 2006, Analytical contract laboratory method summaries and costs, http://minerals.cr.usgs.gov/intranet/chem/labmethods.html, last accessed on February 1, 2006.

Matooka, J., 1996, Organometallic halide extraction for 10 elements by inductively coupled plasma-atomic emission spectrometry, in Arbogast, B., ed., Analytical methods manual for the Mineral Resource Surveys Program, U.S. Geological Survey: U.S. Geological Survey Open-File Report 96-525, p. 102-108.

Taggart, J.E. Jr., 2002, Analytical methods for chemical analysis of geologic and other materials, U.S. Geological Survey: U.S. Geological Survey Open-File Report 02-0223, at http://pubs.usgs.gov/of/2002/ofr-02-0223/, last accessed on January 3, 2006.

Taylor, C.D. and Theodorakos, P.M., 2002, Rock Sample Preparation, in Taggart, J.E. Jr., 2002, Analytical methods for chemical analysis of geologic and other materials, U.S. Geological Survey: U.S. Geological Survey Open-File Report 02-0223, Chapter A1, at http://pubs.usgs.gov/of/2002/ofr-02-0223/, last accessed on January 3, 2006. 